\title{
PEMBELAJARAN FISIKA DENGAN PENDEKATAN CTL MELALUI METODE EKSPERIMEN DAN DEMONTRASI DITINJAU DARI KREATIVITAS DAN GAYA BELAJAR SISWA
}

\author{
Parmono $^{1}$, Widha Sunarno ${ }^{2}$, Suparmi $^{3}$ \\ ${ }^{1}$ Program Studi Pendidikan Sains Program Pascasarjana \\ Universitas Sebelas Maret, 57126, Indonesia \\ parmonogufis@gmail.com \\ ${ }^{2}$ Program Studi Pendidikan Sains Program Pascasarjana \\ Universitas Sebelas Maret, 57126, Indonesia \\ widhasunarno@gmail.com \\ ${ }^{3}$ Program Studi Pendidikan Sains Program Pascasarjana \\ Universitas Sebelas Maret, 57126, Indonesia \\ suparmiuns@gmail.com
}

\begin{abstract}
Abstrak
Tujuan penelitian ini adalah untuk mengetahui pengaruh pendekatan CTL melalui metode eksperimen dan demontrasi ditinjau dari kreativitas dan gaya belajar terhadap prestasi belajar siswa pada ranah kognitif, afektif dan keterampilan proses. Penelitian ini menggunakan metode eksperimen dan dilaksanakan dari bulan Oktober 2012- Januari 2013. Populasi penelitian ini adalah semua siswa kelas XII IPA SMA N 1 Gemolong tahun pelajaran 2012/2013. Sampel diperoleh dengan teknik cluster random sampling yang terdiri dari dua kelas eksperimen. Kelas eksperimen pertama diberi pembelajaran dengan metode eksperimen dan kelas eksperimen kedua diberi pembelajaran dengan metode demontrasi. Data dikumpulkan dengan metode tes untuk prestasi belajar kognitif, angket untuk prestasi afektif, kreativitas, gaya belajar,dan lembar observasi untuk prestasi ketrampilan proses. Hipotesis diuji menggunakan anava (Analisis Variansi). Dari hasil analisis data disimpulkan; 1) ada pengaruh penggunaan metode eksperimen dan demontrasi terhadap prestasi belajar kognitif, afektif, dan keterampilan proses siswa; 2) ada pengaruh kreativitas terhadap prestasi belajar kognitif, afektif dan keterampilan proses siswa; 3) ada pengaruh gaya belajar terhadap prestasi belajar kognitif, afektif, dan keterampilan proses siswa; 4) tidak ada interaksi antara metode dengan kreativitas terhadap prestasi belajar kognitif, afektif, dan keterampilan proses siswa; 5) ada interaksi antara metode dan gaya belajar siswa terhadap prestasi belajar kognitif dan afektif, tetapi tidak ada interaksi antara keduanya terhadap keterampilan proses; 6) ada interaksi antara kreativitas dan gaya belajar terhadap prestasi belajar kognitif, afektif dan keterampilan proses; 7) tidak ada interaksi antara metode, kreativitas dan gaya belajar terhadap prestasi belajar kognitif, afektif dan keterampilan proses.
\end{abstract}

Kata Kunci: pembelajaran fisika, CTL, metode eksperimen, metode demonstrasi, kreativitas, dan gaya belajar. 


\section{Pendahuluan}

Merujuk pada Peraturan Pemerintah No 19 tahun 2005 dan Peraturan Menteri Pendidikan Nasional Nomor 23 tahun 2006 tentang Standar Kompetensi Lulusan Kelompok Mata Pelajaran (SK-KMP) Ilmu Pengetahuan dan Teknologi SMA dapat dipahami bahwa kompetensi lulusan khususnya mata pelajaran ilmu pengetahuan dan teknologi SMA termasuk mata pelajaran fsika yang diharapkan tidak hanya pengetahuan kognitif, tetapi juga pembentukan karakter siswa yang meliputi perkembangan fisik dan psikologis. Agar tujuan pembelajaran fisika dapat dicapai sesuai dengan harapan pemerintah, pelaksanaan pembelajaran harus diusahakan berpusat pada siswa, dengan mempertimbangkan faktor internal dan eksternal siswa.

Catatan TIMSS (Trends in International Mathematics and Science Study) tahun 2007, lembaga yang mengukur pendidikan dunia bahwa penguasaan sains siswa grade 8 negara Indonesia di peringkat ke-36 dari 48 negara. Skor rata-rata yang diperoleh siswa-siswa Indonesia adalah 397. Skor ini masih jauh di bawah skor rata-rata internasional yaitu 500. Selain itu, bila dibandingkan dengan tiga negara tetangga, yaitu Singapura, Malaysia dan Thailand, posisi peringkat siswa Indonesia berada jauh tertinggal. Singapura berada pada peringkat ke-3 dengan skor rata-rata 593, Malaysia berada pada peringkat ke-20 dengan skor rata-rata 474, dan Thailand berada pada peringkat ke-29 dengan skor rata-rata 441

(http://nces.ed.gov/timss/results07/math07.asp).

Prestasi belajar mata pelajaran sains khususnya fisika siswa SMA Negeri 1 Gemolong tahun pelajaran 2011/2012 rendah. Pada tahun itu prestasi belajar siswa mata pelajaran fisika khususnya pada materi gejala gelombang banyak yang masih di bawah kriteria ketuntasan minimum (KKM), sehingga banyak siswa harus remedial untuk menuntaskan materi pelajaran tersebut. Rendahnya prestasi belajar fisika pada materi gejala gelombang disebabkan oleh tingkat kesulitan materi, siswa, guru, metode dan sarana yang mendukung pembelajaran, Materi pelajaran gejala gelombang merupakan materi pelajaran yang komplek, mulai dari sederhana dengan pemikiran konkrit sampai dengan pemikiran abstrak. Dengan kata lain materi gejala gelombang mempunyai tingkat kesulitan yang tinggi. Untuk bisa menguasai materi gejala gelombang diperlukan penguasaan matematika cukup, konsep getaran yang baik dan konsep kinematika gerak yang memadai. Selain itu diperlukan analisa yang kuat untuk mengaplikasikan persamaan matematika ke dalam konsep fisika.

Siswa SMA Negeri 1 Gemolong mempunyai kondisi siswa yang beragam, berbeda tingkat ekonomi keluarga, kecerdasan, motivasi, kreativitas, gaya belajar dan lain-lain. Materi gejala gelombang merupakan salah satu konsep yang kompleks sehingga untuk dapat menguasahi konsep ini diperlukan siswa yang mempunyai kecerdasan yang memadai, motivasi yang cukup, kreativitas yang baik dan gaya belajar yang sesuai. Siswa yang mempunyai kecerdasan dan motivasi yang tinggi akan lebih cepat menguasai materi ini. Siswa yang mempunyai kreativitas tinggi akan memperoleh hasil yang maksimal jika diberi kesempatan untuk mengembangkan kreativitasnya.

Siswa yang mempunyai gaya belajar berbeda akan memperoleh prestasi belajar maksimal jika cara belajarnya sesuai dengan gaya belajar yang dimiliki. Siswa yang mempunyai gaya belajar visual akan lebih mudah belajar dengan gambar dan visualisasi, sehingga siswa ini akan berpretasi jika belajar banyak menggunakan gambar dan visualisasi yang cukup. Siswa auditori akan dapat belajar dengan nyaman jika pembelajaran banyak berhubungan dengan suara. Sedangkan siswa kinestetik akan memperoleh hasil belajar yang maksimal jika diberi kesempatan untuk belajar dengan gerakan-gerakan yang mendukung pada materi yang diperlajari.

Kebanyakan metode pembelajaran yang digunakan di SMA Negeri 1 Gemolong masih metode ceramah. Guru secara aktif menjelaskan materi pelajaran, kemudian contoh soal dan memberi soal-soal latihan. Siswa dianggap mesin, mereka mendengarkan penjelasan guru, mencatat dan mengerjakan soal-soal. Akibatnya interaksi dalam pembelajaran yang muncul hanyalah interaksi satu arah yaitu pengetahuan hanya apa yang disampainkan guru. Padahal banyak penelitian pendidikan yang menyatakan bahwa metode-metode pembelajaran yang baru 
menghasilkan prestasi belajar fisika lebih baik secara signifikan dari pada metode-metode yang lama. Namun hingga saat ini metode-metode baru tersebut tetap juga belum banyak digunakan oleh para guru.

Menurut Piaget dalam Paul Suparno (2006:33) perkembangan kognitif individu meliputi empat tahap, yaitu; a) tahap sensorimotor (0 - 2 tahun); b) tahap pra-operasional (2 - 7 tahun), c) tahap pemikiran operasional konkret (7 - 11 tahun), dan d) tahap operasional formal (11 tahun ke atas). Dalam perkembangan itu pemikiran anak berkembang pelan - pelan mulai dari sensori-motor, lalu ke pemikiran konkrit, dan baru pemikiran abstrak

Pembelajaran fisika menghendaki siswa memiliki pengetahuan tentang fisika sebagai produk, proses dan sikap. Siswa hendaknya menggunakan kemampuan berpikir untuk mendapatkan konsep fisika melalui serangkaian langkah pembelajaran. Mereka menyusun konsepkonsep berdasarkan langkah-langkah metode ilmiah. Semua kegiatan tersebut dilakukan oleh siswa sendiri sehingga mereka memiliki kompetensi melakukan proses belajar untuk mendapatkan pengetahuan yang diharapkan.

Dengan menggunakan pendekatan CTL maka dua pendekatan yang lain dapat terwakili pada sintak CTL. Pembelajaran dengan pendekatan CTL diharapkan dapat mendorong guru dan siswa untuk menghubungkan pengetahuan yang dimilikinya dengan pengalaman mereka dalam kehidupan. Dengan pendekatan CTL proses pembelajaran diharapkan berlangsung alamiah dalam bentuk kegiatan siswa untuk belajar mengalami secara langsung, bukan transfer pengetahuan dari guru ke siswa, namun melalui proses pengetahuan dapat disusun siswa secara alamiah. Pengetahuan akan dikontruksikan siswa antara pengetahuan yang telah dimiliki siswa dengan tema yang dipelajari.

Metode eksperimen melatih siswa untuk melakukan kegiatan percobaan sekaligus berpikir ilmiah, kritis, jujur dan bertanggung jawab. Hasilhasil percobaan yang telah dilakukan dihubungkan dengan pengetahuan awal yang telah mereka pelajari. Jika ternyata ada kesamaan antara konsep yang telah dimengerti dengan hasil eksperimen, maka mereka akan semakin meyakini bahwa pengetahuan mereka benar. Tetapi jika hasilnya berbeda, maka mereka akan mulai berpikir untuk mengetahui apa penyebab perbedaan antara konsep yang telah dibuktikan dengan hasil konsep awal yang mereka miliki.

Metode lain yang sesuai dengan pembelajaran CTL adalah metode demonstrasi. Metode demonstrasi adalah cara penyajian pelajaran dengan memperagakan atau mempertunjukkan kepada siswa suatu proses, situasi, atau benda tertentu yang sedang dipelajari, baik sebenarnya ataupun tiruan, yang sering disertai penjelasan lisan. Dengan metode ini siswa mendapat gambaran secara langsung apa yang dipelajari, walaupun tidak semua siswa dapat memcoba di kelas.

Keberhasilan belajar fisika juga tidak terlepas dari kemampuan individu yang dimiliki siswa yang merupakan faktor internal, yaitu intelegensi quetiont (IQ), motivasi, interaksi sosial, minat, kreativitas dan gaya belajar. IQ siswa sangat bervariasi, ada siswa IQ-nya tinggi, ada siswa yang IQ-nya rendah, demikian juga kreativitas. Siswa yang kreatif pada saat belajar fisika digolongkan berkreativitas tinggi. Sebaliknya siswa yang tidak kreatif pada saat pelajaran fisika bahkan cenderung masa bodoh digolongkan siswa kreatitivitas rendah. Kreativitas rendah dan tinggi ini tentu berpengaruh pada prestasi belajar siswa. Siswa dengan kreativitas tinggi cenderung memperoleh prestasi belajar tinggi, demikian sebaliknya, siswa yang mempunyai kreativitas rendah akan cenderung mempunyai prestasi belajar rendah.

Hasil belajar fisika siswa dipengaruhi oleh gaya belajarnya. Gaya belajar visual dimiliki siswa yang belajarnya lebih mudah dengan mengamati, menggambarkan dengan citra visual. Bagi siswa ini, yang memegang peranan penting dalam belajar adalah mata sehingga guru sebaiknya banyak menggunakan alat peraga atau media. Gaya belajar auditorial adalah gaya belajar siswa yang cenderung mengandalkan telinga untuk menangkap suara atau penjelasan dari guru. Siswa ini akan cenderung berprestasi jika pembelajaran guru dititik beratkan pada diskusi atau ceramah. Gaya belajar kinestetik berbeda dengan dua gaya belajar lainnya. Gaya belajar ini lebih banyak belajar melalui melakukan sesuatu secara langsung 
(bergerak, bekerja dan menyentuh). Siswa yang memiliki gaya belajar kinestetik mengharuskan individu yang bersangkutan melakukan suatu aksi secara langsung yang memberikan informasi tertentu agar ia bisa mengingat atau memahami sesuatu, barulah ia akan memperoleh konsep yang bermakna.

Menurut David Ausubel dalam Ratna Wilis Dahar (2006;94) belajar diklasifikasikan menjadi dua dimensi. Dimensi yang pertama berhubungan dengan informasi atau materi apa saja yang akan disajikan pada siswa melalui peneriman atau penemuan. Dimensi yang kedua berhubungan dengan bagaimana siswa dapat mengkaitkan informasi dengan struktur kognitif yang telah dimiliki. Struktur tersebut berupa fakta, konsep dari generalisasi yang diterima siswa.

Menurut Jerome Bruner dalam Ratna Wilis Dahar (2006:73-77) hal yang penting dalam belajar adalah bagaimana orang memilih, mempertahankan, dan mentransformasi informasi secara aktif. Menurut Bruner proses belajar siswa akan melibatkan tiga hal yang berlangsung hampir saling bersamaan, yaitu: a) memperoleh informasi baru; b) transformasi; c) menguji relevansi dan ketepatan pengetahuan.

Selama belajar siswa menemukan sendiri struktur dasar atau konsep dari materi pelajaran. Cara belajar seperti ini selanjutnya disebut belajar dengan menemukan sendiri (discovery learning) yang menggunakan corak berpikir induktif dengan membuat perkiraan yang masuk akal. Dengan hasil belajar seperti ini, siswa mendapat pengetahuan dan pemahaman yang baru secara langsung mengalami atau menemukan, yang kemudian dikaitkan dengan kerangka kognitif yang dimiliki sehingga dapat merubah kerangka berfikir. Bruner menyarankan agar siswa hendaknya belajar melalui berpartisipasi aktif untuk memperoleh konsep-konsep dan prinsipprinsip agar mereka memperoleh pengetahuan sebagai hasil belajarnya secara maksimal.

Menurut Trianto (2008:17) pembelajaran kontekstual didefinisikan sebagai "konsep mengajar dan belajar yang membantu guru menghubungkan isi pelajaran dengan situasi dunia nyata". Pembelajaran kontekstual merupakan proses pembelajaran inovatif yang membantu siswa menghubungkan isi pelajaran dengan konteks kehidupan. Pembelajaran kontekstual menantang siswa untuk menghubungkan konsep akademik dengan kehidupan sehari-hari dan merangsang siswa untuk berpikir kritis yang membuat pelajaran menjadi efektif dan bertahan lama.

CTL merupakan pendekatan belajar yang membantu guru mengaitkan antara materi yang diajarkannya dengan situasi dunia nyata siswa dan mendorong siswa membuat hubungan antara pengetahuan yang dimilikinya dengan penerapannya dalam kehidupan mereka seharihari. Menurut Elaine B. Johnson (2011:64) "CTL suatu sistem yang menyeluruh. CTL terdiri dari bagian-bagian yang saling terhubung. Jika bagianbagian ini terjalin satu sama lain, maka akan menghasilkan pengaruh yang melebihi yang diberikan bagian-bagiannya secara terpisah". Menurut Trianto (2008:105) CTL memiliki tujuh komponen utama, yaitu: kontruktivisme (Contructivism), inkuiri (Inquiry), bertanya (quetioning), masyarakat belajar (learning community), pemodelan (modeling), dan penilaian autentik (authentic assesment).

Menurut Paul Suparno (2007:77) "metode eksperimen adalah metode pembelajaran yang mengajak siswa untuk melakukan percobaan sebagai pembuktian, pengecekan bahwa teori yang sudah dibicarakan itu memang benar" Sedangkan menurut E. Mulyasa (2011:110) agar pembelajaran dengan menggunakan metode eksperimen berlangsung secara efektif, langkah-langkah yang dianjurkan adalah sebagai berikut; a) menetapkan tujuan eksperimen; b) mempersiapkan alat dan atau bahan yang diperlukan; c) mempersiapkan tempat eksperimen; d) mempertimbangkan jumlah siswa sesuai dengan alat-alat yang tersedia; e) memperhatikan keamanan dan kesehatan agar dapat memperkecil atau menghindarkan resiko yang merugikan atau bahaya; f) memperhatikan disiplin atau tata tertib, terutama dalam menjaga peralatan dan bahan yang akan digunakan; g) memberikan penjelasan tentang apa yang harus diperhatikan dan tahapan-tahapan yang mesti dilakukan siswa termasuk yang dilarang dan yang membahayakan.

Metode mengajar adalah sebuah cara yang dipergunakan guru dalam mengadakan hubungan 
dengan siswa pada saat berlangsungnya pengajaran. Dengan metode yang tepat diharapkan ada berbagai kegiatan belajar siswa sehubungan dengan kegiatan belajar mengajar. Hal yang terpenting dalam metode adalah setiap metode yang digunakan harus mendukung tujuan pembelajaran yang telah dicanangkan, yang dirancang untuk dicapai, sesuai dengan indikator.

Metode demonstrasi banyak digunakan dalam menyajikan pembelajaran IPA. Menurut Paul Suparno (2006:142) pembelajaran demonstrasi diartikan sebagai metode mengajar dengan pendekatan visual agar siswa dapat mengamati proses, informasi, peristiwa, alat dalam pelajaran fisika, dengan tujuan siswa lebih memahami bahan yang diajarkan lewat suatu kenyataan yang dapat diamati. Menurut E. Mulyasa (2011:107) agar pembelajaran menggunakan metode demonstrasi berlangsung secara efektif, langkah-langkah yang dianjurkan adalah sebagai berikut; a) melakukan perencanaan yang matang sebelum pembelajaran dimulai; b) merumuskan tujuan pembelajaran dengan metode demonstrasi; c) membuat garis besar langkahlangkah metode demonstrasi; d) menetapkan apakah demonstrasi tersebut akan dilakukan guru atau oleh peserta didik; e) memumulai demonstrasi dengan menarik perhatian seluruh peserta didik; f) mengupayakan agar semua siswa terlibat secara aktif dalam kegiatan pembelajaran; g) melakukan eveluasi terhadap pembelajaran yang telah dilaksanakan.

Tujuan penggunaan metode demonstrasi antara lain: 1) Siswa mampu memahami tentang cara mengatur atau menyusun sesuatu; 2) Siswa dapat menyaksikan kerja suatu alat atau benda; 3) Siswa dapat mengamati bagian-bagian dari suatu benda atau alat; 4) Bila siswa melakukan sendiri demonstrasi, maka ia dapat mengerti juga penggunaan suatu alat

Kegunaan metode demonstrasi dalam kegiatan belajar mengajar adalah: 1) dapat membuat pengajaran menjadi lebih jelas dan lebih konkret, sehingga menghindari verbalisme; 2) siswa lebih mudah memahami apa yang dipelajari; 3) proses pengajaran menjadi lebih menarik; 4) siswa dirangsang untuk aktif mengamati, menyesuaikan antara teori dan kenyataan, dan mencoba melakukannya sendiri.
Disamping memiliki kelebihan, metode demonstrasi juga memiliki kekurangan, antara lain: 1) Metode ini memerlukan ketrampilan guru secara khusus, karena tanpa ditunjang dengan hal itu, pelaksanaan demonstrasi akan tidak efektif; 2) Fasilitas seperti peralatan, tempat, dan biaya yang memadai tidak selalu tersedia dengan baik; 3) Demonstrasi memerlukan kesiapan dan perencanaan yang matang disamping memerlukan waktu yang cukup panjang, yang mungkin terpaksa mengambil waktu atau jam mata pelajaran lain.

Conny dalam Reni Akbar Hawadi, dkk (2001:4) berpendapat kreativitas adalah kemampuan untuk memberikan gagasan-gagasan baru dan menerapkannya dalam pemecahan masalah. Kreativitas meliputi, baik ciri-ciri aptitude seperti kelancaran (fluency), keluwesan (flexibility), dan keaslian (originality) dalam pemikiran maupun ciri-ciri (non aptitude), seperti rasa ingin tahu, senang mengajukan pertanyaan dan selalu ingin mencari pengalaman-pengalaman baru.

Utami Munandar (2004: 21) berpendapat bahwa kreativitas adalah kemampuan untuk menghasilkan/ menciptakan sesuatu yang baru. Sedangkan menurut Haefele, kreativitas adalah kemampuan untuk membuat kombinasi-kombinasi baru yang mempunyai makna sosial. Karakteristik kreativitas menurut Utami Munandar (2004:71) adalah; 1) Rasa ingin tahu yang luas dan mendalam; 2) sering mengajukan pertanyaan yang baik; 3) memberikan gagasan atau usul terhadap suatu masalah; 4) bebas dalam menyatakan pendapat; 5) mempunyai rasa keindahan yang dalam; 6) menonjol dalam salah satu bidang seni; 7) mampu melihat suatu masalah dari berbagai segi sudut pandang; 8) mempunyai rasa humor yang luas; 9) mempunyai daya imajinasi; 10) orisinil dalam ungkapan gagasan dan pemecahan masalah

Menurut M. Musrofi (2010:59) setiap siswa memiliki kekuatan yang berbeda dalam menyerap materi pelajaran. Ada yang kuat menyerap materi pelajaran melalui mata atau disebut tipe visual. Ada yang kuat menyerap materi pelajaran melalui pendengaran atau disebut pelajar tipe auditori. Ada yang kuat menyerap materi 
pelajaran melalui sentuhan - bau - rasa - gerak atau disebut pelajar tipe kinestetik.

Gaya belajar visual lebih suka menggunakan foto, membuat gambar, bermain warna, dan peta untuk menyampaikan informasi dan berkomunikasi dengan orang lain, ia suka membaca, suka menulis, suka mencoret-coret kertas, lebih menyukai membaca cerita dibandingkan mendengar cerita, cepat dalam melakukan penjumlahan atau perkalian, pintar dalam mengeja kata, dan sering mencatat segala yang diperintahkan. Pembelajar tipe ini dapat dengan mudah memvisualisasikan benda, rencana dan hasil pikiran mata. Selain itu pembelajar visual memiliki kemampuan yang baik tentang tata ruang sehingga mudah memahami peta,untuk mengajar pembelajar visual, gunakan foto, gambar, warna dan media visual lainnya untuk membantu belajar. Pakai alat tulis (spidol, kapur dll) minimal empat warna. Banyak menggunakan "kata visual" dalam ungkapan. Contohnya: lihat, gambar, perspektif, visual, dan peta. Menggunakan peta pikiran (mind map) untuk memberikan penjelasan atau membuat catatan. Menggunakan diagram untuk membantu memvisualisasikan hubungan antara bagian-bagian dari sistem. Memakai teknik bercerita tertentu dapat membantu pembelajar tipe ini untuk menghafal materi yang tidak mudah untuk "dilihat". Beberapa profesi yang sebagian besar menggunakan gaya visual adalah seni visual, arsitektur, fotografi, video atau film, desain, perencanaan, dan navigasi.

Gaya belajar kinestetik lebih banyak belajar melalui melakukan sesuatu secara langsung (bergerak, bekerja dan menyentuh). Siswa yang memiliki gaya belajar ini mengharuskan individu yang bersangkutan melakukan suatu aksi yang memberikan informasi tertentu agar ia bisa mengingat atau memahami sesuatu. Pembelajar kinestetik tak tahan duduk berlama-lama mendengarkan pelajaran dan merasa bisa belajar lebih baik jika prosesnya disertai kegiatan fisik. Pembelajar kinestetik memiliki kemampuan mengkoordinasikan sebuah tim disamping kemampuan mengendalikan gerak tubuh (athletic ability). Pembelajar karakteristik ini dianjurkan untuk belajar melalui pengalaman dengan menggunakan berbagai model peraga, seperti

\begin{tabular}{|lcccc|}
\hline No. & Yang di Uji & $\begin{array}{l}\text { p-value } \\
\text { Kognitif }\end{array}$ & $\begin{array}{l}\text { p-value } \\
\text { Afektif }\end{array}$ & $\begin{array}{l}\text { p-value } \\
\text { Afektif }\end{array}$ \\
\hline 1 & Hipotesis 1 & 0.000 & 0.020 & 0.044 \\
\hline 2 & Hipotesis 2 & 0.000 & 0.033 & 0.035 \\
\hline 3 & Hipotesis 3 & 0.000 & 0.000 & 0.001 \\
\hline 4 & Hipotesis 4 & 0.862 & 0.411 & 0.569 \\
\hline 5 & Hipotesis 5 & 0.025 & 0.031 & 0.161 \\
\hline 6 & Hipotesis 6 & 0.039 & 0.007 & 0.047 \\
\hline 7 & Hipotesis 7 & 0.497 & 0.640 & 0.786 \\
\hline
\end{tabular}

bekerja di lab atau belajar di alam atau sambil bermain.

\section{Metode Peneltian}

Populasi dalam penelitian ini adalah seluruh siswa kelas XII program IPA SMA Negeri 1 Gemolong tahun pelajaran 2012/2013 yang terdiri dari 4 kelas dengan jumlah siswa sebanyak 136 siswa. Teknik pengambilan sampel dalam penelitian ini menggunakan teknik Cluster Random Sampling. Desain penelitian yang digunakan adalah penelitian eksperimen (experimental research) yang berusaha untuk mengetahui pengaruh antara suatu variabel terhadap variabel lainnya. Penelitian ini bersifat eksperimental dengan rancangan data penelitian disajikan dalam desain faktorial $2 \times 2 \times 2$ dengan teknik analisis varians (Anava).

Instrumen yang digunakan berupa silabus, RPP, LKS, modul dan intrumen pengambilan data berupa tes, angket dan rubrik. Instrumen bentuk tes untuk mengukur prestasi kognitif dengan menggunakan tes pilihan ganda dengan satu jawaban benar. Angket untuk mengukur kreativitas, gaya belajar dan prestasi afekrif, sedangkan rubrik digunakan untuk mengukur prestasi ketrampilan proses pada saat pembelajaran. Dokumentasi berupa video saat pembelajaran berlangsung dan foto pada saat pelaksanaan tes. Uji validitas isi intrumen dilakukan oleh ahli sebelum diujicobakan.

Setelah try out, instrumen prestasi kognitif diuji validitas dan reliabilitas butir soal. Untuk instrumen prestasi afektif, kreativitas dan gaya belajar dilakukan uji reliabilitas instrumen. Setelah dihitung menggunakan program Anates diperoleh, 25 soal prestasi kognitif didapatkan 21 soal valid dan 4 soal tidak valid dengan reliabilitas tes sebesar 0.84. Sedangkan prestasi afektif, 
kreativitas dan gaya belajar masing-masing mempunyai reliabilitas $0.89,0.72$, dan 0.82

Data hasil penelitian diuji hipotesis melalui analisis variansi (Anava) tiga jalan menggunakan program SPSS 18.

\section{Pembahasan}

Dari hasi analisis anava diatas, jika p-value $>0.05$, maka Ho diterima sedangkan jika p-value $<0.05$, maka Ho ditolak. Dari data diatas dapat dibahas hipotesis untuk data prestasi belajar kognitif ektif dan keterampilan proses sebagai berikut:

\section{Hipotesis Pertama}

Berdasarkan hasil analisis pengaruh metode pembelajaran eksperimen dan demomstrasi terhadap prestasi belajar menggunakan analisis anava diperoleh nilai probabilitas 0.000 untuk kognitif, 0.020 untuk afektif dan 0.044 untuk keterampilan proses. Sehingga dapat simpulkan bahwa metode eksperimen dan demonstrasi berpengaruh secara signifikan terhadap prestasi belajar kognitif, afektif maupun keterampilan proses. Setelah di uji dengan uji lanjut anava diperoleh siswa yang belajar dengan metode eksperimen mendapat nilai rata-rata kognitif, afektif dan keterampilan proses lebih besar dari pada siswa yang belajar dengan metode demonstrasi, jadi siswa yang belajar dengan metode eksperimen lebih besar pengaruhnya terhadap prestasi belajar kognitif, afektif maupun ketrampilan proses. Hasil ini sesuai dengan hasil penelitian Widodo (2009) yang diperoleh ada perbedaan penggunaan metode eksperimen dan Demonstrasi terhadap prestasi belajar kimia.

\section{Hipotesis Kedua}

Berdasarkan hasil analisis pengaruh kreativitas terhadap prestasi belajar siswa menggunakan analisis anava diperoleh nilai probabilitas 0.000 untuk kognitif, 0.033 untuk afektif dan 0.035 untuk keterampilan proses. Sehingga dapat simpulkan bahwa kreativitas tinggi dan rendah berpengaruh secara signifikan terhadap prestasi kognitif, afektif maupun keterampilan proses. Setelah uji lanjut anava diperoleh siswa yang mempunyai kreativitas tinggi mendapat nilai rata-rata kognitif, afektif dan keterampilan proses lebih besar dari pada siswa yang mempunyai kreativitas rendah, jadi siswa yang mempunyai kreativitas tinggi lebih besar pengaruhnya terhadap prestasi belajar kognitif, afektif maupun ketrampilan proses. Hasil ini didukung oleh penelitian Sriani (2010) memperoleh hasil ada perbedaan kreativitas tinggi dan rendah siswa terhadap prestasi belajar fisika, siswa yang mempunyai kreativitas tinggi prestasinya lebih baik daripada siswa yang kreativitasnya rendah $(\mathrm{p}$-value $=0,000<0,050)$

\section{Hipotesis Ketiga}

Berdasarkan hasil analisis pengaruh gaya belajar terhadap prestasi belajar siswa menggunakan analisis anava diperoleh nilai probabilitas 0.000 untuk kognitif, 0.000 untuk afektif dan 0.001 untuk keterampilan proses. Sehingga dapat simpulkan bahwa gaya belajar kinestetik dan visual berpengaruh secara signifikan terhadap prestasi kognitif, afektif maupun keterampilan proses. Setelah dilakukan uji lanjut anava diperoleh siswa yang mempunyai gaya belajar visual mendapat nilai rata-rata kognitif, afektif dan keterampilan proses lebih besar dari pada siswa yang mempunyai gaya belajar kinestetik, jadi siswa yang mempunyai gaya belajar visual lebih besar pengaruhnya terhadap prestasi belajar kognitif, afektif maupun ketrampilan proses. Hasil ini didukung oleh hasil penelitian Wiwik Winarti (2010) yang memperoleh hasil ada perbedaan prestasi belajar antara siswa yang memiliki gaya belajar visual dan kinestik (p-value $=0,003,0,005$ ).

\section{Hipotesis Keempat}

Berdasarkan hasil analisis interaksi antara metode eksperimen dan demonstrasi dengan kreativitas tinggi dan rendah terhadap prestasi belajar siswa menggunakan analisis anava diperoleh nilai probabilitas $\mathrm{p}$-value $=0.862$ untuk kognitif, $\mathrm{p}$-value $=0.411$ untuk afektif dan p-value $=0.569$ untuk keterampilan proses. Sehingga dapat simpulkan interaksi metode belajar eksperimen dan demonstrasi dengan kreativitas siswa tinggi dan rendah tidak memberikan pengaruh terhadap prestasi belajar kognitif, afektif maupun ketrampilan proses.

Metode dan kreativitas pada saat berdiri sendiri dapat mempengaruhi prestasi belajar siswa, tetapi secara bersama tidak mempengaruhi prestasi 
belajar siswa, hal ini disebabkan karena: a) metode eksperimen menggunakan program matlab, sehingga bagi siswa katagori kreatif tinggi tetapi penguasaan program matlab kurang akan berpengaruh pada proses pembelajaran; b) program matlab memerlukan kapasitas laptop yang memadai karena jika tidak memadai kegiatan ini akan terganggu karena proses laptop berjalan lambat.

Hasil ini didukung oleh penelitian Widodo (2009) yang memperoleh hasil tidak ada interaksi antara metode pembelajaran eksperimen dan demonstrasi dengan kreativitas siswa terhadap prestasi belajar kimia, $\mathrm{p}$-value $=0,083>0,050$ Selain itu selisih rata-rata antara kreativitas tinggi dan rendah untuk kelas eksperimen hampir sama dengan selisih rata-rata antara kreatifitas tinggi dan rendah pada kelas demontrasi, selengkapnya ditampilkan pada tabel 4.1, dengan demikian interaksi antara metode eksperimen dan demonstrasi dengan kreativitas tinggi dan rendah tidak terjadi karena gradien gambar plot hampir sama.

\section{Hipotesis Kelima}

Berdasarkan hasil analisis interaksi antara metode eksperimen dan demonstrasi dengan gaya belajar kinestetik dan visual terhadap prestasi belajar menggunakan analisis anava diperoleh nilai probabilitas $\mathrm{p}$-value $=0.025$ untuk kognitif, $\mathrm{p}$-value $=0.031$ untuk afektif dan $\mathrm{p}$-value $=0.161$ untuk keterampilan proses. Sehingga dapat simpulkan bahwa interaksi metode belajar eksperimen dan demonstrasi dengan gaya belajar kinestetik dan visual berpengaruh secara signifikan terhadap prestasi belajar kognitif dan afektif. Metode belajar eksperimen dan demonstrasi dengan gaya belajar kinestetik dan visual siswa memberikan pengaruh yang signifikan terhadap prestasi belajar kognitif dan afektif .

Sedangkan metode eksperimen dan demonstrasi dengan gaya belajar kinestetik dan visual tidak berpengaruh secara signifikan terhadap prestasi belajar siswa pada keterampilan proses. Metode eksperimen dan demonstrasi dengan gaya belajar kinestetik dan visual siswa tidak memberikan pengaruh secara signifikan terhadap prestasi belajar keterampilan proses. Hal ini disebabkan karena keterbatasan kemampuan pengamat menilai siswa pada saat pembelajaran masih ditambah dengan pengamat tidak hafal nama siswa yang diamati sehingga memperbesar kemungkinan kelemahan penilaian. Selain itu pembelajaran ini banyak melibatkan penggunaan program matlab dimana kemampunan matlab tidak sama, sehingga terlihat pembelajaran didominasi siswa yang menguasai program matlab lebih baik.

Kelas yang menggunakan metode eksperimen pada siswa yang mempunyai gaya belajar visual memperoleh prestasi kognitif paling besar. Sedangkan siswa yang memperoleh prestasi kognitif paling rendah diperoleh pada kelas yang menngunakan metode demonstrasi dan siswa yang mempunyai gaya belajar kinestetik. Jika ditinjau dari metode demonstrasi dan eksperimen, siswa yang mempunyai gaya belajar visual memperoleh prestasi kognitif lebih tinggi dibandingkan dengan siswa yang mempunyai gaya belajar kinestetik.

Jika ditinjua dari gaya belajar, siswa yang mempunyai gaya belajar kinestetik dan diberi metode demonstrasi memperoleh prestasi kognitif lebih rendah daripada siswa yang mempunyai gaya belajar kinestetik dan diberi metode eksperimen. Sedangkan siswa yang mempunyai gaya visual dan diberi metode demonstrasi memperoleh prestasi kognitif dan afektif lebih rendah daripada siswa yang mempunyai gaya belajar visual dan diberi metode eksperimen.

Kelas yang menggunakan metode eksperimen pada siswa yang mempunyai gaya belajar visual memperoleh prestasi afektif paling besar. Sedangkan siswa yang memperoleh prestasi afektif paling rendah diperoleh pada kelas yang menngunakan metode demonstrasi dan siswa yang mempunyai gaya belajar kinestetik. Jika ditinjua dari gaya belajar, siswa yang mempunyai gaya belajar kinestetik dan diberi metode demonstrasi memperoleh prestasi afektif lebih rendah daripada siswa yang mempunyai gaya belajar kinestetik dan diberi metode eksperimen. Sedangkan siswa yang mempunyai gaya visual dan diberi metode demonstrasi memperoleh prestasi afektif lebih rendah daripada siswa yang mempunyai gaya belajar visual dan diberi metode eksperimen.

\section{Hipotesis Keenam}

Berdasarkan hasil analisis interaksi antara kreativitas tinggi dan rendah dengan gaya belajar kinestetik dan visual menggunakan analisis anava 
diperoleh nilai probabilitas $\mathrm{p}$-value $=0.039$ untuk kognitif, $p$-value $=0.031$ untuk afektif dan $p$-value $=0.047$ untuk keterampilan proses. Sehingga dapat simpulkan bahwa interaksi antara kreativitas tinggi dan rendah dengan gaya belajar kinestetik dan visual berpengaruh secara signifikan terhadap prestasi belajar kognitif,afektif, dan keterampilan proses. Interaksi antara kreativitas tinggi dan rendah dengan gaya belajar kinestetik dan visual siswa memberikan pengaruh secara signifikan terhadap prestasi belajar kognitif, afektif dan keterampilan proses.

Siswa yang mempunyai kreativitas tinggi dan gaya belajar visual memperoleh prestasi kognitif paling besar. Sedangkan siswa yang memperoleh prestasi kognitif paling rendah diperoleh siswa yang mempunyai kreativitas rendah dan gaya belajar kinestetik. Jika ditinjau dari kreativitas, siswa yang mempunyai kreativitas rendah dan gaya belajar kinestetik memperoleh prestasi kognitif lebih rendah daripada siswa yang mempunyai kreativitas rendah dan gaya belajar visual. Sedangkan siswa yang mempunyai kreativitas tinggi dan gaya belajar visual memperoleh prestasi kognitif lebih tinggi daripada siswa yang mempunyai kreativitas tinggi dan kinestetik.

Jika ditinjau dari gaya belajar, siswa yang mempunyai gaya belajar visual dan kreativitas rendah memperoleh prestasi kognitif lebih rendah daripada siswa yang mempunyai kreativitas tinggi. gaya belajar kinestetik Siswa yang mempunyai kreativitas tinggi dan gaya belajar visual memperoleh prestasi afektif paling besar. Sedangkan siswa yang memperoleh prestasi afektif paling rendah diperoleh siswa yang mempunyai kreativitas rendah gaya belajar kinestetik.

Jika ditinjau dari kreativitas, siswa yang mempunyai kreativitas rendah dan gaya belajar kinestetik memperoleh prestasi afektif lebih rendah daripada siswa yang mempunyai kreativitas rendah dan gaya belajar visual. Sedangkan siswa yang mempunyai kreativitas tinggi dan gaya belajar visual memperoleh prestasi afektif lebih tinggi daripada siswa yang mempunyai kreativitas tinggi dan kinestetik.

\section{Hipotesis Ketujuh}

Berdasarkan hasil analisis interaksi antara metode dengan kreativitas dan gaya belajar terhadap prestasi belajar siswa menggunakan analisis anava diperoleh nilai probabilitas $\mathrm{p}$-value $=0.497$ untuk kognitif, $\mathrm{p}$-value $=0.786$ untuk afektif dan $\mathrm{p}$-value $=0.569$ untuk keterampilan proses. Sehingga dapat simpulkan bahwa metode belajar eksperimen dan demonstrasi dengan kreativitas dan gaya belajar tidak berpengaruh secara signifikan terhadap prestasi kognitif, afektif maupun keterampilan proses. Interaksi metode belajar eksperimen dan demonstrasi dengan kreativitas gaya belajar siswa tidak memberikan pengaruh terhadap prestasi belajar kognitif, afektif maupun ketrampilan proses.

Pendekatan CTL melalui metode eksperimen dan demonstrasi perbedaannya terletak pada eksperimen lebih leluasa mencoba. Pada pembelajaran ini menggunakan laboratorium virtuil yang menyebabkan perbedaan antara eksperimen dan demonstrasi semakin tipis. Jika ditinjau dari kreativitas siswa metode eksperimen dengan metode demonstrasi dibedakan dari banyak sedikitnya aktivitas siswa. Dengan menggunakan program matlab maka keterbatasan penguasaan program matlab kreativitas siswa akan berkurang. Dengan demikian yang terjadi metode dan kreativitas siswa secara bersama tidak mempengaruhi prestasi belajar siswa.

\section{Kesimpulan}

bahwa:

Hasil penelitian ini dapat disimpulkan

1. Siswa yang diberikan pembelajaran dengan metode eksperimen memperoleh prestasi belajar rata-rata kognitif, afektif dan keterampilan proses lebih tinggi dari metode demonstrasi.

2. Siswa dengan kategori kreativitas tinggi memperoleh prestasi belajar rata-rata kognitif, afektif dan keterampilan proses lebih tinggi dari pada kreativitas rendah.

3. Siswa dengan gaya belajar visual memperoleh prestasi belajar rata-rata kognitif, afektif dan keterampilan proses lebih tinggi dari pada gaya belajar kinestetik.

4. Siswa dengan gaya belajar visual diberi pembelajaran metode eksperimen 
memperoleh prestasi rata-rata konitif dan afektif lebih tinggi dari pada gaya belajar visual diberi pembelajaran metode demonstrasi.

5. Siswa gaya belajar visual dengan kreativitas tinggi memperoleh prestasi belajar rata-rata kognitif, afektif dan keterampilan proses paling tinggi. Sedangkan gaya belajar kinestetik dengan kreativitas rendah meperoleh prestasi belajar rata-rata paling rendah.

\section{Saran}

Dari hasil penelitian disarankan kepada guru untuk menggunkan pembelajaran metode eksperimen untuk meningkatkan prestasi belajar pada materi gejala gelombang.

\section{DAFTAR PUSTAKA}

Elaine B. Johnson. 2009. CTL Contextual Teaching \& Learning Menjadikan Kegiatan Belajar Mengajar Mengasikkan dan Bermakna. Jakarta. Kaifa.

E. Mulyasa. 2011. Menjadi Guru Profesional. Bandung. PT Remaja Roda Karya.

\section{....., 1997. Filsafat Konstruktivisme dalam} Pendidikan. Yogyakarta. Kanisius

\section{......., 2007. Metodologi Pembelajaran Fisika} Kontruktivistik dan Menyenangkan. Yogyakarta. Universitas Sanata Darma.

Paul Suparno. 2007. Metodologi Pembelajaran Fisika Kontruktivistik dan Menyenangkan. Yogyakarta. Universitas Sanata Darma.

Ratna Wilis Dahar. 2006. Teori-Teori Belajar dan Pembelajaran. Jakarta. Erlangga.

Sriani. 2010. Pembelajaran Fisika Berbasis Masalah dengan Metode Demonstrasi dan Eksperimen ditinjau dari Sikap lmiah dan Kreativitas terhadap Prestasi Belajar. Tesis Pascasarjana Universitas Sebelas Maret Surakarta

Trianto. 2007. Model-Model Pembelajaran Inovatif Berorientasi Konstruktivistik. Jakarta. Prestasi Pustaka.
2008. Mendesain Pembelajaran Kontekstual di Kelas. Jakarta. Cerdas Pustaka Publisher

Utami Munanar. 2004. Pemanduan Anak Berbakat. Jakarta. Rajawali.

M. Musrofi. 2010. Melesatkan Prestasi Akademik Siswa. Yogyakarta. PT. Pustaka Intan Madani.

Widodo. 2009. Pembelajaran Kimia Dengan Pendekatan Kontekstual melalui Metode Eksperimen dan Demonstrasi Ditinjau dari Kreativitas dan Sikap Ilmiah Siswa. Tesis Program Pascasarjana Universitas Sebelas Maret Surakarta.

Winkel, W. S. 1996. Psikologi Pengajaran. Jakarta. Grasind.

Wiwik Winarti .2010. " Penggunaan Laboratorium riil Dan Virtual Pada Pembelajaran Kimia Ditinjau dari Motivasi Berprestasi Dan Gaya Belajar Siswa." Tesis Pasca Sarjana Universitas Sebelas Maret Surakarta 